\title{
The Malaysian Branch of the Royal Asiatic Society
}

\author{
Founded in 1877
}

Just published: Monograph No. 20. SRIWIJAYA

History, Religion and Language of an early Maritime Malay Polity. Price: $\$ \$ 48 /-\quad$ Postage: $\$ \$ 4 /-$

Recently published: Monograph No. 22.

The MBRAS Book of over 1,600 Malay Proverbs with explanations in English.

Price: $\$ \$ 30 /-\quad$ Postage: $\$ \$ 4 /$ -

Awaiting early publication: Monograph No. 21 .

A History of Kelantan.

\section{$* * * * * * * * * * * * *$}

The Society's Journal is published in June and December each year and is ISSUED free to members.

Annual Subscription:

Ordinary Members : $\$ \$ 30 /$ per year

Institutional Members : $\$ \$ 50 /$ per year

Office Address : 130M. Jalan Thamby Abdullah

off Jalan Tun Sambanthan

Brickfields

50470 Kuala Lumpur

Malaysia 


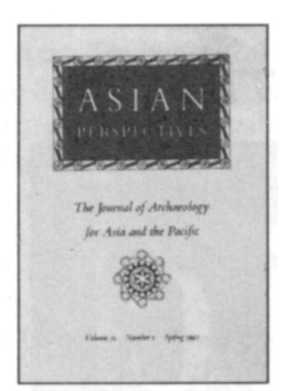

\section{Asian Perspectives}

Devoted to the prehistory of Asia and the Pacific regions and the leading archaeological journal on the area for more than 30 years. The semiannual journal features articles on archaeology, ethnoarchaeology, palaeoanthropology, and book reviews.

\section{RECENT AND FORTHCOMING ARTICLES}

The Palaeolithic in Southern China John W. Olsen and Sari Miller-Antonio

Compositional Analysis of Pottery from North Sumatra:

Implications for Regional Trade

John Miksic, Yap Choon Teck, and V. Vijiyakumar

Temporal Variation in Polynesian Fishing Strategies

Melinda S. Allen

Cultural and Biological Differentiation in Peninsular Malaysia Peter Bellwood

Design Changes in Heiau Temple Architecture on Maui Michael Kolb

\section{SPECIAL ISSUES}

Hawaiian Archaealogy (Spring 199I)

Prehistoric Exchange in Oceania (Fall 1990)

INDIVIDUALS: US\$24/YEAR; INSTITUTIONS: US\$30/YEAR. AIRMAIL: ADD US\$12/YEAR

\section{University of Hawaii Press}

Journals Department, 2840 Kolowalu St., Honolulu, HI 96822, USA Telephone (808) 956-8833 


\section{Established 1927 \\ Isn't it time to subscribe?}
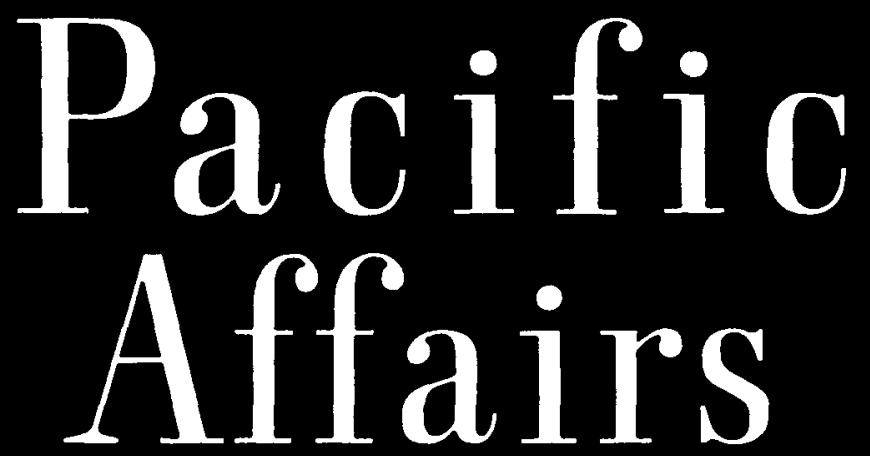

PEACEFUL OR DANGEROUS COLLABORATORS?

CHINA'S RELATIONS WITH THE

GULF COUNTRIES

John Calabrese

RUSSIA AND THE ASIA-PACIFIC REGION

Leszek Buszynski

LEADERSHIP AND BILATERAL RELATIONS: MENZIES AND NEHRU, AUSTRALIA AND INDIA, 1949-1964

Meg Gurry

WOMEN AND REVOLUTION IN NORTH KOREA

Kyung Ae Park

BOOK REVIEWS

Vol. 65 , No. 4

Winter 1992-93

\section{In International Review of Asia and the Pacilic}

Pacific Affairs

The University of British Columbia

Vancouver, BC, Canada V6T 1Z2

Published Quarterly

Annual subscription rates: Individuals $\$ 35$; Institutions $\$ 50$.

Postage outside Canada \$5 


\title{
JOURNAL OF SOUTHEAST ASIAN STUDIES
}

The Journal of Southeast Asian Studies is published for the Department of History, National University of Singapore, by Singapore University Press (Pte) Ltd in March and September. Contributions are invited from scholars working in all disciplines in the Humanities and Social Sciences, and should deal with the Philippines, Indonesia, Brunei, Singapore, Malaysia, Burma (Myanmar), Thailand, Cambodia, Laos or Vietnam. The editorial board prefers manuscripts of 4,000 to 8,000 words oriented toward a readership composed of scholars from various disciplines, but written to be accessible to non-specialists. Material should be fully documented and of enduring value; analyses of current affairs which may quickly fall out of date, and pieces containing policy prescriptions, are rarely accepted. Before a manuscript can be published, it must conform to the Journal's style sheet which is available upon request. Submission of an article will be taken to mean that it has not been previously published and that it is not on offer to any other publisher. Contributors are encouraged to submit articles using electronic mail, or to submit hard copy computer printouts, whenever possible. Authors receive a complimentary copy of the issue of the Journal in which their piece appears, and 30 offprints.

Material appearing in the Journal of Southeast Asian Studies does not necessarily represent the views of the Editors or the publisher, and responsibility for opinions expressed and the accuracy of facts published in articles rests solely with the individual authors.

Editorial correspondence, requests for permission to reprint articles, and contributions should be directed to:

\author{
The Editor \\ Journal of Southeast Asian Studies \\ c/o Department of History \\ National University of Singapore \\ 10 Kent Ridge Crescent \\ Singapore 0511
}

The Fax number for the Journal is (65) 7742528 , and electronic mail can be sent to the Journal's BITNET address: SHIS@NUS3090.

\section{SUBSCRIPTIONS}

Subscription rates are as follows:

$$
\begin{aligned}
& \text { Singapore : } \$ \$ 36.00 \text { per volume (2 issues) } \\
& \text { Malaysia : } \$ \$ 44.00 \text { per volume (2 issues) } \\
& \text { Foreign : US } \$ 27.00 \text { per volume (2 issues) }
\end{aligned}
$$

Prices quoted are inclusive of postage by registered mail. Payment may be made by credit card (American Express, Visa and Mastercard) or bankdraft.

Subscription enquiries and all business correspondence should be addressed to:

\author{
The Editor/Manager \\ Singapore University Press (Pte) Ltd \\ Yusof Ishak House \\ 10 Kent Ridge Crescent \\ Singapore 0511
}

Fax (65) 7740652

Articles appearing in the Journal are abstracted or indexed in America: History and Life; Biography Index; Humanities Index; Historical Abstracts, Part A: Modern History Abstracts; Historical Abstracts, Part B: Twentieth Century Abstracts; Recently Published Articles (Amèrican Historical Association); $A B C$ POL SCI; Petroleum Abstracts; Geographical Abstracts; Human Geography; International Development Abstracts; International Political Science Abstracts; Index of Islamic Literature.

Published by

Singapore University Press (Pte) Ltd

National University of Singapore
Typeset by: Letraprint

Printed by: Hup Soon Printing 


\section{NOTES ON CONTRIBUTORS}

ROBERT IVESSING is a Consultant with the Madura Research Centre in Indonesia.

BERNARD SELLATO is a Free Lance Consultant and currently serving as Director of Culture and Conservation Programme in East Kalimantan for World Wide Fund for Nature.

GEOFF WADE is a Ph.D. candidate, Department of History, University of Hong Kong.

MARK W. MCLEOD is an Assistant Professor in the Department of History, University of Delaware, U.S.A.

MARTIN STUART-FOX is a Reader in History at the University of Queensland, Australia.

MICHAEL S. BILLIG is an Associate Professor of Anthropology and Director of Asian Studies at Franklin and Marshall College, Lancaster, Pennsylvania, U.S.A. 